University of Wollongong

Research Online

Faculty of Law, Humanities and the Arts Papers (Archive)

$1-1-2017$

Examining the Chinese-Australian post-production relationship through Chinese audiences' cinema experience

Kai Ruo Soh

University of Wollongong, krs354@uowmail.edu.au

Follow this and additional works at: https://ro.uow.edu.au/lhapapers

Part of the Arts and Humanities Commons, and the Law Commons

Research Online is the open access institutional repository for the University of Wollongong. For further information contact the UOW Library: research-pubs@uow.edu.au 


\section{Examining the Chinese-Australian post-production relationship through Chinese audiences' cinema experience}

\section{Keywords}

chinese-australian, examining, audiences', chinese, experience, relationship, cinema, post-production

Disciplines

Arts and Humanities | Law

\section{Publication Details}

Soh, K. "Examining the Chinese-Australian post-production relationship through Chinese audiences' cinema experience." Studies in Australasian Cinema 11 .3 (2017): 122-136. 


\title{
Examining the Chinese-Australian post-production relationship through Chinese audiences' cinema experience
}

\author{
Kai Soh \\ Law, Humanities and the Arts, University of Wollongong, Wollongong, Australia
}

\begin{abstract}
In recent years, China has become one of the largest film industries and in order to remain competitive, Chinese blockbusters are attempting to imitate Hollywood post-production qualities. As Australian post-production companies are internationally renowned for their expertise, Chinese filmmakers are seeking opportunities to collaborate with Australians. The Australian government recognises China's enthusiasm and has begun highlighting the nation's strength through various programmes targeted towards the Chinese film industry. Though efforts have been placed to promote Australia's post-production industry, there is currently minimal research on Chinese cinema audiences' opinions regarding this transnational collaboration. To examine the effects of transnationality in Chinese cinema, this paper analyses Chinese audiences' opinions, along with exploring how the Australian government and post-production companies are engaging with China, to understand the potential of this partnership. The paper utilises data collected from the Chinese social networking site Douban to understand audiences' reception on the post-production elements of the Chinese film Hero (2002). Overall, the analysis demonstrates that Chinese audiences are not identifying Australia's role, however the impact of Australian practitioners are being emphasised through complements on the film's visual effects, showing great potential between this transnational collaboration.
\end{abstract}

\section{ARTICLE HISTORY}

Received 20 June 2017

Accepted 25 September 2017

\section{KEYWORDS}

Australian post-production;

Chinese-Australian

collaboration; cinema

audience; transnational

cinema; social networking

sites

\section{Introduction}

Over the past few years, the Chinese film industry has implemented strategies in pursuant of becoming Hollywood's largest competitor, including attempts to imitate Hollywood's special effects and quality in order to stay competitive. In order to so, Chinese filmmakers are engaging with post-production companies outside of Mainland China (China) in an effort to create productions of similar quality, which identifies with the concept of transnational films. According to (Berry 2010; 2013), the term 'transnational' emerged around the same period as the widespread discourse of globalisation towards the end of the twentieth century. Similar to cultural globalisation, 'transnationalism' is complex to define as it holds various definitions based on how the term is being utilised. Within the context of 
cinema studies, Berry (2010, 2013) along with Higbee and Lim (2010) have argued that scholars tend to use this term too generally, with little attempts to provide a definition. This paper is aware of the previous limitation, and has placed an emphasis on examining the imbalances of power within the transnational context of this research.

Hollywood productions are associated to transnational films, as they are generally preproduced, filmed and post-produced across several countries or within the same country but at several locations. According to film producer Ian Smith - during the 6th Beijing International Film Festival's Co-production Forum -, Hollywood is a brand and not a representation of a physical location, as productions seek international experts to create films for audiences worldwide. From a box office perspective, Hollywood films are perceived as films that can appeal to audiences' globally, not confining to a specific market, and are therefore perceived as the model formula for the 'global blockbuster'. However, the strategy of utilising the 'Hollywood brand' as a model for Chinese film production do present disadvantages, as seen in Zhang Yimou's international collaboration The Great Wall (2016), where the film received criticism for casting Matt Damon in a Chinese story as the film's protagonist (Ge 2016). On the other hand, the Chinese blockbuster Wolf Warrior 2 (2017) broke box office records in China for the film's portrayal of Westerners as the bad guys, along with the film's patriotism to China. According to industry news, the success of Wolf Warrior 2 has left Hollywood to rethink their collaborative strategy with China (Frater 2017). Although within international collaborations the industry focuses on narrative and casting decisions, this paper moves away from cultural characteristics and focuses on the influence of 'Hollywood's' post-production quality in Chinese cinema through hiring practitioners within the Hollywood circle.

In this aspect, Australian post-production companies have an advantage due to their extensive portfolio of Hollywood blockbusters which China is pursuing to follow. As Australian post-production companies are venturing into the Chinese film market, this research seeks to analyse Chinese filmgoers experience to understand the effects of transnationality in Chinese cinema and to explore the potential of this partnership. The paper examines the post-production industry in Australia along with the analysis of audiences' comments from the Chinese blockbuster Hero (Zhang 2002).

It is important to note that although Hero was released more than a decade ago, the film currently stands as a significant case study, as it was the first Chinese blockbuster with services from Soundfirm and Animal Logic, two of the largest and most established Australian post-production companies. Within English-language academia, the film has been the topic of many academic discussions on Chinese cinema, including a book dedicated to the film edited by Rawnsley and Rawnsley (2010).

This paper provides insights into how Chinese audiences are reacting to the shift in the quality of production 15 years ago through Australian's expertise, by examining comments on the Chinese Social Networking Site (SNS) Douban (豆瓣) from 2005 to 2016. The research explores how the Australian government and companies are engaging with China through various commercial and political strategies. The paper also analyses Chinese audiences' reception on the Chinese blockbuster Hero (2002), to understand how Australians are contributing to Chinese cinema along with Chinese audiences' reactions to these changes (or lack thereof.) 


\section{The commercial and political relationship between the Australian and Chinese film industry}

The Chinese film market has always held considerable allure for Australian filmmakers. Australian filmmakers have been enthusiastically seeking out opportunities to work with the Chinese since Australia signed a co-production treaty with China under the Howard government in 2006. International co-productions are seen as a strategy to assist in developing the national cinema of participating countries in order to create a local presence alongside dominant imports within local and international film markets (Hoskins, McFadyen, and Finn 1999; Khoo 2014). Generally, international co-productions are utilised to promote cultural exchange, facilitate joint project financing and to create new distribution channels for the collaborative project (Morawetz et al. 2007). International co-productions can be classified into two categories: official and unofficial co-productions. Unofficial co-productions are approved by two or more production companies from different countries without any government assistance, while official co-productions are based on formal agreements between governments through a treaty or Memorandum of Understanding (MOU; Miller et al. 2001). To date, Australia has signed 10 co-production treaties with Canada, China, Germany, Ireland, Israel, Italy, South Korea, Singapore, South Africa along with the United Kingdom and Northern Ireland. Two MOUs are also currently in force with New Zealand and France. ${ }^{1}$

Since the establishment of the treaty between Australia and China, the Australian government - particularly The Department of Communications IT, and the Arts, Screen Australia ${ }^{2}$ and Ausfilm ${ }^{3}$ - have been actively encouraging Australian filmmakers to work together and broaden their Asian cultural knowledge through 'build [ing]' their Asian capability and cultural adaptability' (Screen Australia 2013). Despite the official efforts placed by the Australian government, Australia is still considered a 'junior partner' within this co-production relationship. The term 'junior partner' in film co-production refers to the relationship between marginal and dominant partners (Goldsmith, Ward, and O'Regan 2010; Yue 2014). In other words, Australia is more dependent towards China and requires China's partnership more than China needs Australia.

Generally, Australian filmmakers face several challenges when producing films with the Chinese, including policy, censorship and cultural complications. Producing film content between Australia and China may be viewed as a challenge. Nonetheless, both nations are striving towards developing a healthy co-production relationship (Andreacchio 2013; Walsh 2012). Within this relationship, China receives several benefits including access to Australia's landscape, which holds a wide range of enticing shooting locations that is available tax-free, as well as to Australia's post-production services. Throughout the years, Australian owned post-production companies have worked on many big-budget Hollywood films, including Guardians of the Galaxy 2 (2017), Mad Max: Fury Road (2015) and The Hunger Games: Mockingjay (2010), providing opportunities for Chinese partners to acquire knowledge and skills from Australian practitioners. Screen Australia and Ausfilm continuously highlights the strength of the Australian post-production industry by steadily promoting the sound and visual effects sectors through organising co-production forums and familiarisation tours 
aiming to attract Chinese filmmakers to engage Australian services as well as shooting locations (Johnson 2016). This includes the Australia-China Co-production Forum, Australia-China Film Industry Exchange ${ }^{4}$ - held in conjunction with the Beijing International Film Festival -, and the Industry Familiarisation Tour held in Australia for Chinese filmmakers to tour studio spaces. Australia is also considered a good option for mid-range producers to internationalise their film within English-language cinema, as Australia provides a cheaper alternative to Hollywood and the United Kingdom (Peng 2016; Walsh 2012).

The Australian government supports and encourages foreign filmmakers to work with local companies through the introduction of the Post, Digital and Visual Effects (PDV) offset, when employing post-production services from an Australian company. The PDV offset - administered by Screen Australia - is an Australian Federal Incentive that offers a 30\% tax rebate for qualifying PDV expenditure according to the Qualifying Australian Expenditure on Film (QAPE) ${ }^{5}$ (Screen Australia 2017). Within the postproduction sector this includes (http://www.ausflm.com.au):

- the conception of audio or visual effects;

- editing and mixing of audio and visual effects;

- any related activities including salaries, per diems and travel costs for PDV staff and crew (regardless of nationality as long as work is conducted in Australia), rental of applicable facilities and equipment.

Productions may also have the option to work with various PDV facilities, but QAPE can only be claimed by one company in-charge of all post-production activities, with a minimum claim of AUD500,000. Productions may receive a 30\% return on total spent on PDV services in Australia and combine this offset with other State grant/s or incentives. To receive the PDV offset, films are not required to attain official co-production status or to fulfil any cultural or content tests, as long as collaborations take place with an Australia post-production company and receive a PDV Final Certification by the Australian Taxation Office (ATO). Films with co-production status are available to utilise both the PDV offset and Production offset, creating a greater incentive for foreign filmmakers to coproduce with Australia.

Examining the Australian and Chinese relationship, Australian post-production services are able to provide Chinese productions with a range of benefits through their transnational experiences. Major Australian post-production companies have been established for over two decades, with an extensive portfolio of Hollywood films, allowing practitioners to sustain and develop their technology through research and development innovation. Examples of several well-established Australian companies include: Rising Sun (22 years), Animal Logic (26 years), Soundfirm (32 years) and Spectrum (53 years). ${ }^{6}$ Being aware that Chinese filmmakers are seeking to imitate Hollywood's production quality, post-production companies greatly emphasise their growth and learning experiences through working in Hollywood, which was observed during the 2016 Australia-Chinese Co-production Forum. ${ }^{7}$

Since the first recorded Chinese film with Australian post-production work - Sun Valley (1995) -, the partnership between Australia's post-production companies and Chinese filmmakers has continued on, especially within visual effects and sound sectors 
(Media Entertainment and Arts Alliance 2005; Walsh 2012). Several Australian companies have contributed to several Chinese blockbusters (大片), providing films with Hollywoodlike special effects well recognised by global audiences (Farquhar 2009). Currently, Soundfirm and Animal Logic are two of the most active Australian post-production companies within the Chinese film industry. Both companies are well-known globally for their postproduction services through their portfolio and awards.

In 2003, China Film Assist - a Chinese production services company - invested in the audio post-production company Soundfirm, allowing the establishment of an office in Beijing. This led to collaborations with several Chinese blockbusters including The Monkey King (2014), Red Cliff (2008), The Curse of the Golden Flower (2006), House of Flying Daggers (2004), Kungfu Hustle (2004) and Hero - which won Best Sound Design at the 2003 Hong Kong Film Awards. On the contrary, Animal Logic, a visual effects company, does not have a physical presence in China, but have been working closely with several Chinese directors including Chen Kaige and Zhang Yimou. Animal Logic's CEO and co-founder Zareh Nalbandian mentioned in an interview that the company is known in China for their 'high-end' work, and is currently holding a great reputation within the Chinese film industry (ACCI 2013). The company has a portfolio of Chinese blockbusters including Chen's Monk Comes down the Mountain (2015), Zhang's House of Flying Daggers (2004) and Hero. The company won Best Visual Effects at the 2003 Hong Kong Film Awards for Hero, as well as Best Visual Effects Award at the 2005 Satellite Award for House of Flying Daggers. Both Soundfirm and Animal Logic conducted postproduction work on Hero, which was both companies' inaugural Chinese blockbuster.

\section{Examining Hero and understanding Chinese cinema audience reception}

Hero, directed by Chinese filmmaker Zhang Yimou, is set during the Warring State Period during China's division of seven kingdoms: Yan, Zhao, Chu, Han, Wei, Qi and Qin. The King of Qin (Chen Daoming) was seen as the most powerful King and intends to unify the country, making him a target for assassination. When one of his prefects known as Nameless (Jet Li) arrives to the Qin capital city, he proves to the king that he defeated three of his enemies: Broken Sword (Tony Leung), Flying Snow (Maggie Cheung) and Long Sky (Donnie Yen). Curious, the King requested Nameless to tell his story as the film follows Nameless' recount. However, while listening to the story, the King saw through Nameless' deceit and desire to assassinate him. The King then told Nameless what he believed actually took place and order his execution.

Hero is a prime example of Chinese transnational cinema, as the film is produced in collaboration with technical and artistic personnel across national borders (Higbee and Lim 2010). According to the film's director, he intentionally created Hero as a global blockbuster, targeting the global market (Farquhar 2009; Lau 2007; Stringer and Yu 2007). In order to create this global blockbuster, Zhang selected a simple narrative while focusing on the film's visual effects and sound, through the hiring of filmmakers and companies within the Hollywood circle. From a box office perspective, the film did well worldwide, earning a total of 177.4 million USD (Hero 2017). Nonetheless, the perception of success also lies within the audience and their opinions, as the film's level of success can be identified through comparing audiences' opinions with the director's intended purpose. 


\section{Understanding audiences' opinions}

Comprehending audiences' opinions allows researchers to evaluate the success of strategies implemented by the film industry and to develop empirically based approaches (Soh \& Yecies 2017). Following the uses and gratification approach, the paper conceptualises that audiences are active in consuming film content, and their opinions provided are based on their individual characteristics and preferences, highlighting the importance of understanding the audience's demographics (Katz \& Lazarsfeld 1955 Papacharissi and Rubin, 2000). Hence, the interpretation of the text by the audience could differ based on their preferences, also known as audience taste. According to Bourdieu (1984), taste is not universal but based on the active cultural practices that is constantly producing and reproducing social systems and hierarchies. Therefore, different groups of audiences within the mass audience may have various opinions of the same text, which differs with the author's (director) intended meaning (Hall 1980). This research identifies its audiences based on Douban's audience profile, which is discussed in the next section.

Traditionally, collecting audiences' opinions was complicated process as it was labour intensive, costly and time consuming. However, with the Internet and SNS, the collection process has been simplified, creating new pathways for researchers and businesses to gain insights into their target audience through analysing their SNS activities (Soh \& Yecies 2017). Within media and cultural studies, the measurement and understanding of audiences' opinions include the utilisation of surveys, analysis of audience comments and the use of a rating system. Quantitative and qualitative surveys have also previously been employed to understand audiences' behaviours and responses to films, while rating systems have been used to analyse cultural influences on consumers' choices (Barker and Mathijs 2008; Filieri 2015; Koh, Hu and Clemons 2010; Yoon 2012).

\section{Collecting Chinese audiences' opinion on the Chinese social networking site - Douban}

In China, the Internet and SNS are seen as a significant communication tool. The number of Internet users in China has steadily increase over the past decade with over 731 million Internet users at the end of 2016, doubling the number of users in 2009. Among Chinese Internet users, $77 \%$ are active on SNS, illustrating the wealth of information available online (CCNIC 2017). Previous studies have also shown the important role SNS among young Chinese consumers, as they are likely to trust and become influenced by people they 'follow' online. Chinese users also show high levels of online engagement by actively offering, searching for and sharing their opinions (Chu and Choi 2011; Yang 2013). This demonstrates the credibility of Chinese SNS comments as recommendations are seen as reliable and taken earnestly among Chinese netizens. Aware of the increasing penetration of SNS in China, this research aims to augment existing research on cinema audience, box office statistics and film texts by including audience analysis based on the Chinese SNS Douban.

Douban was launched in 2005 as a platform that allows users to interact, review, and post recommendations on books, music and film, together with the ability to create their own communities based on their personal interest. Non-registered users are able to access up to $80 \%$ of the site's content. Registered users have the additional ability to rate and 
review book, music and film pages, as well as replying to reviews left by other users. Douban is also known as a 'follower' network, allowing users to follow other users without knowing them personally, and discovering users based on their interests and content they interact with. Douban's primary audience consist of white-collar workers along with Chinese university students, who are interested in a wide range of cultural products. Users are generally considered to be more critical than the mass audience in China, given their heightened exposure to cultural globalisation and its effects (Soh \& Yecies 2017). It is important to note that audiences' opinions analysed here are not a representation of the mass audience, but a subgroup in line with Douban's primary audience. Douban offers a rich and ready source of information on both foreign and domestic cultural products, which are available in China through official or unofficial channels. Beyond China, Douban has become a wellknown source of critical cultural reviews, and Western media outlets in particular have been using the site as a barometer of a film's success with Chinese audiences (Yecies et al. 2016). Douban has also seen an increase in users, where in 2017, 13.6\% of all Internet users in China are active on Douban, a $2.1 \%$ increase from $11.15 \%$ in 2015 , showing the significance and rising popularity of the platform (CNNIC 2017).

Looking specifically at a section on Douban known as Douban Film (豆瓣电影), the page allows users to categorise films on the personal profile using three categories: already watched (看过) or would like to watch (想看), allowing users to interact based on their shared taste in films, which is presented on their profile. Individual film pages also allow users to interact through three categories: 'short commentary' (短评), 'questions' (问题) and 'film review' (影评). Users can rate a film on a 5-point Likert-type scale, where one star denotes 'least satisfied' and five stars 'most satisfied'.

\section{Methodology}

This paper analyses both the short commentary texts and the rating tagged to the comment, utilising both qualitative and quantitative methods. The short commentary section allows users to post a maximum of 140 Chinese characters. The assumption here is that users are more likely to comment on the most important aspect of the film, which can either be positive or negative. The dataset was collected with the assistance of the SMART Infrastructure Facility at the University of Wollongong, using a method that involves 'scraping' the comments. ${ }^{8}$ Scraping imitates the action of a person surfing the Internet, acquiring data from web pages and putting it into a usable format (Skelton 2012). The comments and their associated data were scraped from Douban's publicly available application programming interface (API), which enables data to be extracted and saved. The data collection process was completed on 27 February 2017, with a total number of 13,440 comments collected, with an average rating of 6.7. It important to take note that Douban was only established in 2005, while Hero was released in 2002, which may explain the low number of comments in comparison to more recent Chinese blockbuster hits, where comments are at an average of 140,000. ${ }^{9}$ Figure 1 illustrates the number of comments on Hero per year. As presented in Figure 1, there is a steady increase of comments yearly, with a slight dip in 2013 and 2014. This could be due to the boycott of Zhang's film in China, as he was fined for breaching China's one-child policy ( $\mathrm{Ng} 2014$ ). Majority of the comments were posted in 2016, before the release of Zhang's latest blockbuster The Great Wall. ${ }^{10}$ 


\section{Audiences Comments on Hero from 2005 to 2016}

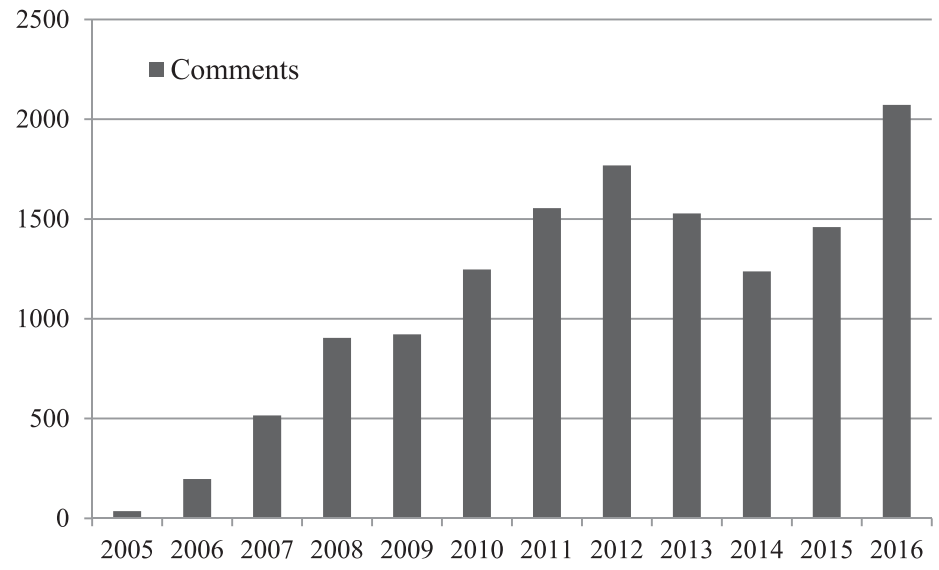

Figure 1. Number of comments made on Hero per year.

The biggest limitation of this research is not having the ability and resources to conduct an in-depth analysis of all 13,440 comments. The analysis was conducted with the assistance of the qualitative data analysis application - NVivo - consisting of two stages, which provided an overview of the comments posted on Douban. The first stage involves identifying a list of frequently used words by utilising the word frequency query function on NVivo as seen in Table 1. Using NVivo enables the identification of the terms most frequently mentioned by users with minimum personal bias involved. By using this method, the analysis reveals the aspects of the films that resonates the most with Chinese audiences.

Unlike previous research conducted on Douban Film, there was less focus on the actors, but more on the film aesthetics and the film as a whole, as reflected in Table 1 (Soh \& Yecies 2017). The second stage entails a keyword selection from the word frequency search to identify comments for analysis. As the paper's main aim is to analyse the post-production aspect of the film, keywords and opinions on the film's narrative and cultural implications were not included in the analysis. Keywords selected for analysis were in the top six: film (电影), beautiful (美), scene (画面), Zhang Yimou (张 艺谋), colour (色彩) and Hero (英雄). Comments containing the selected keywords were manually analysed and personally translated $^{11}$ with the aim of analysing opinions on the film's post-production elements. Chinese terms for 'post-production', 'visual effects' and 'special effects' were not included in the keyword selection, as the study's

Table 1. Most frequently used keywords in Douban user comments on Hero.

\begin{tabular}{llcc}
\hline English & Chinese & Frequency & Weighted Percentage \\
\hline Film & 电影 & 2,194 & 1.56 \\
Beautiful & 美 & 1,742 & 1.24 \\
Scene & 画面 & 1,697 & 1.20 \\
Zhang Yimou & 张艺谋 & 1,488 & 1.03 \\
Colour & 色彩 & 957 & 0.68 \\
Hero & 英雄 & 901 & 0.64 \\
Story & 故事 & 886 & 0.63 \\
China & 中国 & 867 & 0.62 \\
Whole world/ All under heaven & 天下 & 624 & 0.44 \\
Plot & 剧情 & 568 & 0.40 \\
\hline
\end{tabular}


main focus is to identify what audiences are discussing about the film to measure the influence of this transnational collaboration, rather than creating boundaries to identify certain elements. Comments selected for translation for presentation in this paper represent the general consensus of audiences' opinions in each category.

\section{Findings and discussion of Douban audiences' comments}

Majority of the comments from the dataset focused on the appearance of the scenes along with commenting on the achievement and growth of Chinese cinema since the release of Hero. A user commented in 2012:

'This film is China's first guide to creating a commercial film, showing the ability to retain a respective amount of art and not entirely selling out. The mixture of the solid colours of black, red, blue, green and yellow with the special effects was visually pleasing.'

(中国大导们初试商业片的首部作品, 保留了不少艺术气息, 尚未商业到庸俗的地 步。黑、红、蓝、绿、黄, 纯色的大量应用加上特技, 视觉效果很好。）

Another user commented in 2015:

'This is the product of achievement in Chinese cinema. Since the release of this film, domestic commercial blockbusters in China started to develop.'

(中国电影史上里程碑似的作品。从此, 国产商业大片在中国的电影土地上得到了长 足的发展 )

94 percent of the total comments discussed post-production elements of the film including visual effects, colouring and the visual appeal of the scenes, rather than the narrative or actors as seen in a previous study on Korean film remakes in China (Soh \& Yecies 2017). One user commented in 2013:

'After re-watching Hero, Zhang Yimou, brought out the most beautiful scenarios out of my imagination. It is really magnificent.'

(重温了一遍英雄, 张艺谋把我心目中最美的场景都拍出来了呀, 真是美轮美负。)

In 2015:

'Watching the scenes [visually], the action, special effects and colours of the film will allow one to be overwhelmed with enjoyment in this accessible martial arts film ...'

(就画面, 动作, 特技, 色彩来看是一部让人沉醉的写意武侠 ...)

There were also negative comments, but constitute the minority. A user commented in 2015:

'... There was however too much use of colour and special effects in order to develop the film to become more aesthetically pleasing. This makes the film seem artificial!'

(... 不过过多的使用色彩和特技想把电影往唯美那发展就显的有些做作了! )

Although this paper focus is not on the film's narrative, an interesting finding appeared during the analysis. Almost two thirds of the comments (at 64\%) disliked the film's narrative. A user commented in 2010: 
'The beautiful scenes are not able to cover up the empty plotline.'

(华丽的画面掩盖不了空洞的剧情。)

In 2011:

'Watched it many years later (after the film was released), the scenes [visually] are good, however the narrative ......'

(多年后再看 画面很好 故事就 ......)

'Ignoring the plot, the scenes were beautifully.'

(故事情节放一边 画面还是挺漂亮的)

An increase of ratings from 2005 to 2016 is also present in the dataset, with a slight decrease in 2007 as illustrated in Figure 2 below:

The ratings corresponds with the comments and previous research conducted by $\mathrm{Yu}$ (2010) on Hero's Chinese Internet film audiences behaviour from 2003 to 2004. Yu's research suggests that young adults watching the film during the initial release was motivated to comment negatively as they wanted to be part of the trending online conversation which was critical of the film. This data (from 2005 to 2016) shows a different set of analysis, where audiences' were less negative and harsh towards the film in both ratings and comments. However, this could be because comments of the film's narrative was not analysed. Looking at the film's rating, it seems that the fad of criticising Hero continued on to 2005 before dying down in 2006. The film holds its highest average rating in 2016.

Another assumption here is that audiences posting on Douban watched the film more than twice, as comments were posted at a minimum of three years after the film's release date. $14.5 \%$ of the total comments explicitly mention watching the film more than once. A user commenting in 2011:

'When I was young, the school brought us on an excursion to the cinema to watch this film. At that time, I could not understand anything. When I think back, the memory (of the film) is very vague. After re-watching the film, [I realised] this film is really beautiful. Haha. Anyways I was fascinated.'

(小时候学校组织去金钟影院去看, 结果必然是看不懂, 现在想起来也记忆模糊了, 重温了一下, 真漂亮, 哈哈。反正我是看入迷了。)

Average Audience Rating on Hero from 2005 to 2016

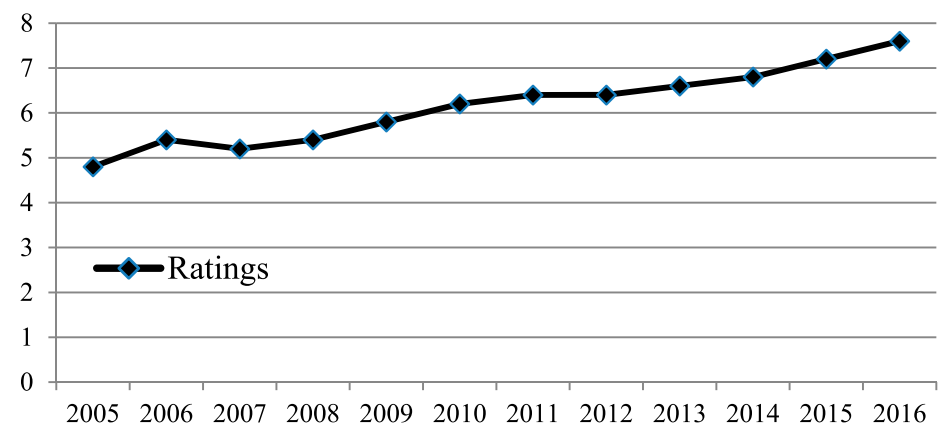

Figure 2. Average audience rating on Hero per year from Douban users. 
In 2016:

'... Watching it back on 9 October 2016, this film has been underestimated. In comparison to films today, this film is not particularly bad.'

(2016.10.9 翻回来看这部电影还是被低估了, 至少放到现在来看也不算特别差)

Based on the dataset, the assumption follows that audiences' are more reflective, as audiences are likely to have watched the film more than once and the fad of criticising Hero has also faded.

Audiences were also aware that Hero was intentionally created to be a global blockbuster, imitating 'Western', or more specifically the 'Hollywood brand', and therefore holds a weak narrative. In 2006, a user commented:

'Although I do not think that the meaning behind this film is deep enough, it is a good film to
show Westerners what is "martial arts", and also in a way a reflection of Chinese culture. In
addition, the scenes are exquisite, which suits foreigner's taste. It can be said that Zhang
Yimou's film are not made for Chinese audiences.'

（虽然我并不认为这部电影的道理够深遂, 但它很好地向西方人反映了“武侠”, 也可 以说反映了中国传统文化, 另外画面精美, 这一点也很合老外口味。可以这么说, 张艺谋的电影，不都是为了中国人拍的。。）

'When it comes to colour, there is no other film as beautiful as Hero. However, the visually stunning film does not cover up the fact that the narrative is lacking. This style suits a foreigner's taste'

(论色彩, 没有再比英雄更漂亮的电影了。可是漂亮的外表下掩盖不了故事的空洞, 这倒是很合老外的胃口。)

Another comment from 2013:

'[In Hero], Zhang Yimou perfectly demonstrated the film's aesthetics and also achieved great commercial success with this production. However, it attempts to excessively appeal to Western audiences' taste, but does not reflect social reality, which made it deliberately mystifying and lacklustre in the narrative.'

(张艺谋将镜头美学和形式主义发挥到极致而又在商业推广上极尽成功的一部作品, 过于迎合西方人趣味使其不接地气故弄玄虚，故事性上乏善可陈)

Based on the comments, the most important aspect of this film was the visual presentation of each scene. Be that as it may, an additional manual search of 'Australia (澳洲)' resulted in zero comments, and is therefore assumed that audiences are not aware of Australia's involvement in this transnational collaboration.

\section{Conclusion}

Similar to any global film production, post-production companies and their employees are the silent heroes behind a successful film, perhaps to preserve the idea of 'movie magic'. A simple on-site observation at the cinema theatre will show that audiences leave before the end credits finish rolling, unless incentives to stay are implemented. Therefore, the recognition of post-production companies are likely ignored by the mass audience. Hero is not an exception. The hidden reality of such transnational collaborations is not 
new, however, the mass audience need not identify all nations participating in the production in order for a film to be 'transnational'.

The findings presented in this paper suggest that the industry is aware of Australia's significance through the awards and praises for Hero, but is largely overlooked by audiences. Looking specifically at this case study, audiences are not aware of the transnational nature of Hero. Chinese audiences largely applaud the visual artistry that the film presents, but mainly acknowledge Zhang rather than the post-production companies involved. Though the mention of Australia or Australian companies is clearly missing in the dataset, the impact of Australia's Animal Logic is emphasised through the comments, as audiences' praises the film's colour and artistry. Chinese audiences' are also wellaware of Zhang's intention in creating Hero as a global blockbuster through the film's imitation of Hollywood's characteristics, which was not entirely welcomed.

The idea of the transnational partnership between Chinese filmmakers and Australian post-production companies show great potential, although praises from audiences were not explicitly for Australians. This does not seem to be an issue with Australian practitioners and the government, as observed during the 2016 Australia-Chinese Co-production Forum. Presentations by Ausfilm and post-production companies show that they are not trying to overcome the lack of awareness among the cinema audiences, but to increase awareness among Chinese filmmakers of the potential Australian skill sets can provide to a production. The participation of Australian post-production companies' in the Chinese film industry has increased Chinese cinema audiences' expectation within the elements of post-production, especially among the visual effects sector. Screen Australia's and Ausfilm's efforts in promoting and assisting Australian post-production companies in China are presenting results. To date, Australian companies that have worked and are working on Chinese productions include: Animal Logic, Soundfirm, Cutting Edge, DPP Studios (formerly Digital Pictures), Spectrum Films and Rising Sun. However, Australian post-production companies are presently seen as 'high-end' and costly due to the strong Australian Dollar against the Chinese Yuan, high employee wages, and having the ability to charge a higher premium due to their working relationship with Hollywood. Australian post-production companies are also competing against South Koreans and local Chinese production companies, who can offer a much lower rate, albeit at a slight decrease in quality.

Theoretically, the reputation of the Australian post-production industry could assist in enticing prominent Chinese filmmakers in creating official international co-productions, which is strongly encouraged by the Australian government based on the incentives on offer. However, based on observation at the 2016 Australia-Chinese Co-production Forum, pitches from both Australian and Chinese filmmakers are mostly presented by independent filmmakers or mid-size production companies with a modest budget. Australian post-production companies are not able to support current Australia-Chinese co-productions due to budget constraints. Currently, in the eyes of Chinese filmmakers, Australia's film industry and post-production industry are on different reputation levels, where the post-production sector is currently a global leader. In conclusion, the biggest predicament faced by Australia post-production industry lies between supporting the Australian national film industry or to remain globally competitive through transnational partnerships, which is currently where it is heading towards. 


\section{Notes}

1. As of May 2017.

2. Screen Australia administers the official co-production programme on behalf of the Australian Federal government.

3. Ausfilm assist in the connection of international industries to Australian opportunities.

4. Previously known as the Australia-China Film Industry Forum.

5. QAPE calculates goods and services provided in Australia among other criteria.

6. As of 2017.

7. Held in conjunction with the International Chinese Film Festival in Sydney, Australia.

8. UOW SMART (University of Wollongong Simulation, Modelling, Analysis, Research and Teaching) focuses on applied infrastructure research.

9. This was calculated by taking the average of The Mermaid (2016) at 173,481 comments, Monster Hunt (2015) at 100,772 and Mojin: THE Lost Legend (2015) at 141,041 comments as of 25 April 2017.

10. As the collection was completed on February 2017, 2017 posts were not included in the analysis to ensure fair calculation.

11. The author is bilingual in both English and Mandarin.

\section{Acknowledgement}

I would like to thank my supervisors Dr Brian Yecies and Dr Xiaoping Gao (University of Wollongong, Australia) for providing invaluable feedback on my paper.

\section{Disclosure statement}

No potential conflict of interest was reported by the author.

\section{Notes on contributor}

Kai Soh is a PhD candidate in the School of the Arts, English and Media at the University of Wollogong. Her research explores the transformation of the Chinese film industry since China joined the World Trade Organisation in 2001. Her research specifically investigates international film coproductions and collaborations with China through the analysis of Chinese audiences' opinions on the Chinese social networking site in order to understand the transnational elements of the Chinese film industry through audience reception.

\section{ORCID}

Kai Soh (1D) http://orcid.org/0000-0002-4379-2955

\section{References}

ACCI. 2013. Case Study: Animal Logic. Canberra: Australian Chamber Commerce and Industry. Andreacchio, M. 2013. "Beyond the Great Wall - Pathways to Australia-China Co-Productions." Australia Film Television and Radio School. Accessed July 21, 2016, https://www.aftrs.edu.au/ media/books/ScreenBusiness/sb-whitepaper/index.html.

Barker, M., and E. Mathijs, eds. 2008. Watching the Lord of the Rings: Tolkien's World Audience. New York: Peter Lang.

Berry, C. 2010. "What is Transnational Cinema? Thinking from the Chinese Situation." Transnational Cinemas 1 (2): 111-127. 
Berry, C. 2013. “Transnational culture in East Asia and the logic of assemblage." Asian Journal of Social Science 41 (5): 453-470.

Bourdieu, P. 1984. Distinction: A Social Critique of the Judgement of Taste. Translated by R. Nice. Massachusetts, MA: Harvard University Press.

Chu, S., and S. M. Choi. 2011. "Electronic Word-of-Mouth in Social Networking Sites: A CrossCultural Study of United States and China." Journal of Global Marketing 24 (3): 263-281.

CNNIC. 2017. "Statistical Report on Internet Development in China." China Internet Network Information Center. Accessed June 7, 2017, https://cnnic.com.cn/IDR/ReportDownloads/ 201611/P020161114573409551742.pdf.

Farquhar, M. 2009. “Digital Imaginaries: Zhang Yimou's Hero and Sydney’s Animal Logic'.” In 21st Century China: Views from Australia, edited by M. Farquhar, 204-222. Newcastle: Cambridge Scholars Publishing.

Filieri, R. 2015. "What Makes Online Reviews Helpful? A Diagnosticity-Adoption Framework to Explain Informational and Normative Influences in e-WOM." Journal of Business Research 68 (6): 1261-1270.

Frater, P. 2017. "Wolf Warrior IIs' Massive Success Forces Studios to Rethink China Approach." Variety. Accessed September 13, 2017, http://variety.com/2017/biz/news/china-wolf-warrior-ii$1202543266 /$.

Ge, C. 2016. “China's Most Expensive Film 'The Great Wall' Fails to Excite Filmgoers, or LeEco Shareholders'” Business Insider. Accessed September 13, 2017, http://www.businessinsider. $\mathrm{com} /$ china-the-great-wall-failure-2016-12?IR=T.

Goldsmith, B., S. Ward, and T. O'Regan. 2010. Local Hollywood: Global Film Production and the Gold Coast. St Lucia: University of Queensland Press.

Hall, S. 1980. "Encoding/Decoding." In Culture, Media, Language: Working Papers in Cultural Studies 1972-1979, edited by S. Hall, D. Hobson, A. Lowe, and P. Willis, 128-138. London: Hutchinson.

Hero. 2017. Box Office Mojo. Accessed May 22, 2017, http://www.boxofficemojo.com/movies/?id= hero02.htm.

Higbee, W., and S. H. Lim. 2010. "Concepts of Transnational Cinema: Towards a Critical Transnationalism in Film Studies.” Transnational Cinemas 1 (1): 7-21.

Hoskins, C., S. McFadyen, and A. Finn. 1999. "International Joint Ventures in the Production of Australian Feature Films and Television Programs." Canadian Journal of Communication 24 (1): 127-139.

Johnson, T. 2016. “China Looks to Australia for Film Production Opportunities." Film Ink. Accessed November 2016, https://filmink.com.au/2016/china-looks-to-australia-for-filmproduction-opportunities/.

Katz, E., and P. F. Lazarsfeld. 1955. Personal Influence: The Part Played by People in the Flow of Mass Communications. New York: Free Press.

Khoo, O. 2014. "Bait 3D and the Singapore - Australia Co-Production Agreement: From Content to Creativity Through Stereoscopic Technology.” Transnational Cinemas 5 (1): 1-13.

Koh, N. S., N. Hu, and E. K. Clemons. 2010. "Do online reviews reflect a product's true perceived quality? - An investigation of online movie reviews across cultures." Proceedings of the 43rd Hawaii International Conference on System Sciences, 1.

Lau, J. K. W. 2007. “Hero: China's Response to Hollywood Globalization.” Jump Cut, 49. Accessed November 8, 2016, http://www.ejumpcut.org/archive/jc49.2007/Lau-Hero/.

Media Entertainment and Arts Alliance. 2005. "Inquiry Into Australia’s Relationship With China." In Submission to Senate Foreign Affairs, Defence and Trade References Committee. Sydney: Media Entertainment and Arts Alliance.

Miller, T., N. Govil, J. McMurria, and R. Maxwell. 2001. Global Hollywood. London: British Film Institute.

Morawetz, N., J. Hardy, C. Haslam, and K. Randie. 2007. "Finance, Policy and Industrial Dynamics -The Rise of Co-Productions in the Film Industry." Industry and Innovation 14 (4): 421-443. 
Ng, N. 2014. “China: Filmmaker Zhang Yimou Fined \$1.2M for Breach of One-Child Policy.” CNN. Accessed June 10, 2017, http://edition.cnn.com/2014/01/09/world/asia/filmmaker-one-childpolicy-fine/index.html.

Papacharissi, Z., and A. M. Rubin. 2000. "Predictors of Internet Use.” Journal of Broadcasting \& Electronic Media 44 (2): 175-196.

Peng, W. 2016. "Chasing the Dragon's Tail: Sino-Australian Film Co-Productions." Media International Australia 159 (1): 73-82.

Rawnsley, G. D., and M. T. Rawnsley. 2010. Global Chinese Cinema: The Culture Politics of Hero. Oxfordshire: Routledge.

Screen Australia. 2013. Common Ground: Opportunities for Australian Screen Partnership in Asia. Canberra: Screen Australia.

Screen Australia. 2017. "Producer Offset." Screen Australia. Accessed April 24, 2017, https://www. screenaustralia.gov.au/getmedia/7aca56fc-d523-4cee-a336-7c6340395252/Guidelines-produceroffset.pdf.

Skelton, C. 2012. "Why You Should Learn Web Scraping and the e-Book That Can Help." Media 15 (3): 37.

Soh, K., and B. Yecies. 2017. "Korean Chinese Film Remakes in a New Age of Cultural Globalisation: Miss Granny and 20 Once Again along the Digital Road." Global Media and China 2 (1): 74-89.

Stringer, J., and Q. Yu. 2007. “Hero: How Chinese is it?" In World Cinema's 'Dialogues' With Hollywood, edited by P. Cooke, 238-254. New York: Palgrave Macmillan.

Walsh, M. 2012. "At the Edge of Asia: The Prospects for Australia-China Film Co-Production." Studies in Australasian Cinema 6 (3): 301-316.

Yang, H. 2013. "Market Mavens in Social Media: Examining Young Chinese Consumers' Viral Marketing Attitude, eWOM Motive, and Behavior." Journal of Asia-Pacific Business 14 (2): 154-178.

Yecies, B., J. Yang, A. Shim, K. Soh, and M. Berryman. 2016. “The Douban online social media barometer and the Chinese reception of Korean popular culture flows." Participations: Journal of Audience \& Reception Studies 13 (1): 114-138.

Yoon, S. "A social network approach to the influences of shopping experience on e-WOM." Journal of Electronic Commerce Research 13 (3): 213-223.

Yu, S. Q. 2010. "Camp Pleasure in an Era of Chinese Blockbusters: Internet Reception of Hero in Mainland China." In edited by G. D. Rawnsley and M. T. Rawnsley, 135-151. London: Routledge.

Yue, A. 2014. “Contemporary Sinophone Cinema: Australia-China Co-Productions.” In Sinophone Cinemas, edited by A. Yue and O. Khoo, 185-222. New York: Palgrave Macmillan.

Zhang, Y. 2002. Hero [DVD]. Beijing: Beijing New Picture Film. 